\title{
Returnee Managers and Enterprise Innovation Performance-Based on the Corporate Risk-Taking
}

\author{
Jing Qiao \\ College of Economics, Jinan University, Guangzhou, China \\ Email: qiaoq_j@163.com
}

How to cite this paper: Qiao, J. (2019) Returnee Managers and Enterprise Innovation Performance-Based on the Corporate Risk-Taking. Modern Economy, 10, 615623.

https://doi.org/10.4236/me.2019.103042

Received: February 18, 2019

Accepted: March 5, 2019

Published: March 8, 2019

Copyright (อ 2019 by author(s) and Scientific Research Publishing Inc. This work is licensed under the Creative Commons Attribution International License (CC BY 4.0).

http://creativecommons.org/licenses/by/4.0/

\begin{abstract}
This paper uses the data of 224 Chinese listed companies from 2007 to 2017 to study the relationship between returnee managers, risk-taking and corporate innovation performance. The research results show that the returnee managers are significantly positively correlated with the innovation performance of the enterprise; the returnee managers are positively related to the enterprise risk-taking; the risk-taking is the mediator of the returnee managers and the innovation performance of the enterprises.
\end{abstract}

\section{Keywords}

Returnee Managers, Corporate Risk-Taking, Innovation Performance

\section{Introduction}

Innovation is an important force to promote the development and progress of enterprises. General Secretary Xi Jinping has repeatedly emphasized the important role of "innovation" in China's comprehensive deepening of reform and development. The important role of "innovation" in enterprise development is self-evident, and if the enterprises want to survive and thrive in a fiercely competitive environment, they need constant innovation. In the process of enterprise innovation investment decision-making, the role of managers is extremely critical. It is also a key figure for enterprises to enhance their competitiveness, and is also one of the important driving forces.

The Upper Echelons Theory [1] believes that the relevant characteristics of managers affect their choices, which in turn affects the company's strategy and its role in corporate performance. Among them, returnee managers have an international vision and relationship resources, and the impact on corporate per- 
formance is self-evident. So what is the impact of returnee managers on corporate innovation performance? How does it affect the innovation performance of the enterprises? This paper uses the data of 224 listed companies in China from 2007 to 2017 to explore the relationship between returnee managers and corporate innovation performance, and takes risk-taking as a mediator to further study the mutual relationship between returnee managers, risk-taking and corporate innovation performance, and provides new ideas for improving the innovation performance of enterprises.

\section{Literature Review and Research Hypothesis}

Existing researches are mostly based on the interaction of managers' background, risk-taking and corporate innovation performance. The research focuses on the following three perspectives:

The relationship between managers', after background characteristics and corporate innovation performance. Cheng et al. [2] found that the management team's educational background, age and term of office have a significant positive impact on corporate performance; Zhu Guojun et al. [3] said that the professional background, age, and term heterogeneity of the executive team can promote the improvement of enterprise's innovation technology performance, education level, professional and tenure heterogeneity can improve the financial performance of enterprises, and the heterogeneity of education can enhance the innovation strategy performance of enterprises; Han Qingyi et al. [4] said the education level and functional background of the senior management team are positively affecting the innovation efficiency of the enterprise; Liu et al. [5] found that there are obvious knowledge spillover effects in returnee managers, it can promote enterprise innovation to a certain extent, and thus affect the level of innovation in the industry; Wang Xueli et al. [6] said that the management team with an overseas background has a positive impact on the company's short-term performance, long-term performance, innovation performance and overseas performance; Liu Fengchao et al. [7] indicates that the overseas background ratio of the senior management team can promote the number of patent applications of enterprises, but its impact on the return on net assets of enterprises is not obvious.

The relationship between managers' background and risk-taking. Wang Yonghai et al. [8] indicated that the educational level of decision makers affects their attitude towards risk. The education level of the highest decision makers is proportional to the risk management of enterprises; Lu Wendong et al. [9] found that the level of risk-taking of enterprises is affected by the age, gender and education level of managers. The education level of the manager is directly proportional to the level of risk tolerance of the company; Su Kun [10] found that the background characteristics of CEO's age, education level and so on affect the company's risk tolerance level, and the degree of education of the CEO is negatively correlated with the level of risk-taking of the company. 
Bargeron et al. [11] said the higher the risk-taking level, the more investment opportunities the company uses, the more R\&D expenditures, and the stronger the innovation ability of the company, the greater the competitiveness in the market; Brown et al. [12] indicates that risk-taking is positively related to enterprise innovation; Liu Hua et al. [13] indicated that moderate risk-taking of enterprises contributes to their innovation; Yang Jianjun et al. [14] said that risk-taking behavior affects whether the company is innovative and how to innovate.

It can be seen that above literature focuses on the interaction between managers' characteristics, risk-taking and corporate innovation performance. Few literature include the three into a research framework to discuss the relationship between the three. This paper takes the listed companies in China from 2007 to 2017 as the research object, empirically analyzes the relationship between the three and verifies the following hypotheses:

Hypothesis 1: Returnee managers can positively promote the improvement of corporate innovation performance.

Hypothesis 2: Returnee managers affect the level of risk-taking of enterprises, and the two are positively correlated.

Hypothesis 3: Risk-taking is a mediator variable for returnee managers and corporate innovation performance.

\section{The Model Design}

1) Sample selection and data source

This paper takes the panel data of 224 listed companies in China from 2007 to 2017 as the research object, and excludes the following listed companies: a) listed companies with incomplete information disclosure; b) incomplete disclosure of patent applications or no patent applications Listed company; c) listed companies with missing financial data; d) financial listed company; e) companies that exclude ST and terminate listing. The classification of the industry mainly includes mining industry, manufacturing, wholesale and retail trade, building industry, information transmission, software and information technology services.

The data comes from CSMAR, Wind and RESSET, among them, the overseas background data of managers is derived from CSMAR's "Characteristics of Listed Companies" database, Risk-taking data from wind, the patent application data is derived from CSMAR's "Listed Companies and Subsidiary Patents" database, and other financial data comes from CSMAR and RESSET.

2) Variable design

a) Explanatory variables: Referring to the research results of domestic and foreign scholars, this article defines managers as president, vice president, general manager, deputy general manager, CEO, CFO, board secretary and other managers announced in the annual report. The explanatory variable is the proportion of managers with overseas background to the total number of managers, and the indicator is named FSM. 
b) Interpreted variables: This paper draws on Wang Lanfang et al. [15] to measure the innovation performance of enterprises, and measure the innovation performance of enterprises with the number of patent applications, and named the indicators as Patent.

c) Intermediary variables: For risk-taking, this paper draws on the research of Jiang Fuxiu et al. [16] and uses the Z-score model to measure the financial risk of enterprises as a substitute for risk taking.

$$
\text { Z-score }=1.2 X_{1}+1.4 X_{2}+3.3 X_{3}+0.6 X_{4}+0.999 X_{5}
$$

Among them, $X_{1}$ is working capital/total assets, $X_{2}$ is retained earnings/total assets, $X_{3}$ is profit before interest and taxes/total assets, $X_{4}$ is total market value/total liabilities, and $X_{5}$ is operating income/total assets. Generally speaking, when the Z-score is greater than 2.675, it indicates that the financial status of the enterprise is good. When the Z-score is less than 1.81, it indicates that the enterprise has a large risk of bankruptcy, when the Z-score is between the 1.81 and 2.675 , it indicates that the company is in a gray area.

d) Control variables: This paper uses the enterprise scale, operating income growth rate, asset-liability ratio, equity concentration, executive compensation, annual dummy variables and industry dummy variables as control variables. The variables are defined as follows: (Table 1)

3) Model setting

The model is constructed as follows: Model 1 is used to analyze the relationship between returnee executives and enterprise innovation performance, and to verify hypothesis 1, building Model 2 to explore the impact of returnee managers

Table 1. Variable definitions.

\begin{tabular}{|c|c|c|c|}
\hline Variable type & Variable name & $\begin{array}{l}\text { Variable } \\
\text { symbol }\end{array}$ & Variable definitions \\
\hline Interpreted variables & Innovation performance & Patent & Logarithm of the number of patent applications of enterprises \\
\hline Explanatory variables & Returnee Managers & FSM & $\begin{array}{l}\text { the proportion of managers with overseas background } \\
\text { to the total number of managers }\end{array}$ \\
\hline \multirow[t]{4}{*}{ Intermediary variables } & Risk-taking & Z-score & Z-score $=1.2 X_{1}+1.4 X_{2}+3.3 X_{3}+0.6 X_{4}+0.999 X_{5}$ \\
\hline & Enterprise scale & Size & Natural logarithm of total assets \\
\hline & $\begin{array}{l}\text { Operating income } \\
\text { growth rate }\end{array}$ & Growth & $\begin{array}{l}\text { (Annual amount for the current year - amount for the same period of } \\
\text { the previous year)/(Amount for the same period of the previous year) }\end{array}$ \\
\hline & Assets and liabilities & LEV & Total liabilities/total assets \\
\hline \multirow[t]{4}{*}{ Control variables } & Manager salary & Pay & The logarithm of the top three managers' total compensation \\
\hline & $\begin{array}{l}\text { Number of independent } \\
\text { directors/number } \\
\text { of directors }\end{array}$ & Ind & Number of independent directors/number of directors \\
\hline & year & Year & virtual variable \\
\hline & Industry & Industry & virtual variable \\
\hline
\end{tabular}


on corporate risk taking to verify hypothesis 2 . On this basis, we use the managers' overseas background, risk-taking as the independent variable, and the enterprise's innovation performance as the dependent variable to explore the mediating effect of risk-taking, and verify the hypothesis 3.

The specific inspection steps are as follows: According to the research model of Wen Zhonglin et al. (2005) [16], centralize all variables and construct OLS Model of returnee managers and enterprise innovation performance (model 1) to test the coefficient. If it is not significant, the test is stopped. If the coefficient is significant, construct the OLS model of the returnee managers and the risk-taking (model 2) and the OLS model of returnee managers, risk-taking and enterprise innovation performance (model 3), and then test the regression coefficients. If the regression coefficients of both models are significant, It means that at least part of the influence of the independent variable on the dependent variable is realized by the intermediate variable. If at least one regression coefficient is not significant, then proceed to Sobel (1982) test.

$$
\begin{aligned}
\text { Patent }= & \alpha+\beta_{1} \mathrm{FSM}+\beta_{2} \mathrm{Size}+\beta_{3} \mathrm{Growth}+\beta_{4} \mathrm{LEV}+\beta_{6} \mathrm{CR} 1 \\
& +\beta_{7} \mathrm{Pay}+\beta_{8} \mathrm{Ind}+\sum \text { Year }+\sum \text { Industry }+\varepsilon \\
\text { Z-score }= & \alpha+\beta_{1} \mathrm{FSM}+\beta_{2} \mathrm{Size}+\beta_{3} \text { Growth }+\beta_{4} \mathrm{LEV}+\beta_{6} \mathrm{CR} 1 \\
& +\beta_{7} \mathrm{Pay}+\beta_{8} \mathrm{Ind}+\sum \text { Year }+\sum \text { Industry }+\varepsilon \\
\text { Patent }=\alpha & +\beta_{1} \mathrm{FSM}+\beta_{2} \mathrm{Size}+\beta_{3} \text { Growth }+\beta_{4} \mathrm{LEV}+\beta_{6} \mathrm{CR} 1 \\
+ & \beta_{7} \text { Pay }+\beta_{8} \text { Ind }+\beta_{9} \text { Z-score }+\sum \text { Year }+\sum \text { Industry }+\varepsilon
\end{aligned}
$$

\section{Empirical Analysis}

1) Descriptive statistics

From Table 2, it can be seen that for different enterprises, there is a big difference in the proportion of returnee managers who account for the total number of senior managers, the maximum is 0.917 and the minimum is 0 . For Z-score, most enterprises is greater than 2.675. It shows that its financial status is good and the risk is small. For the innovation performance of enterprises, the

Table 2. Descriptive statistics.

\begin{tabular}{ccccccc}
\hline Variable & Obs & Mean & Std. & Minimum & Median & Maximum \\
\hline FSM & 2464 & 0.039 & 0.101 & 0 & 0 & 0.917 \\
Z-score & 2464 & 4.262 & 5.696 & -5.607 & 2.681 & 84.451 \\
Patent & 2464 & 1.414 & 0.669 & 0 & 1.342 & 3.815 \\
Size & 2464 & 2.758 & 0.607 & 1.144 & 2.674 & 5.381 \\
Growth & 2464 & 0.198 & 0.192 & -0.374 & 0.175 & 1.662 \\
LEV & 2464 & 0.506 & 0.183 & 0.056 & 0.513 & 2.024 \\
Ind & 2464 & 0.365 & 0.051 & 0.091 & 0.333 & 0.667 \\
CR1 & 2464 & 0.372 & 0.150 & 0.036 & 0.360 & 0.864 \\
Pay & 2464 & 6.19 & 0.342 & 4.982 & 6.187 & 7.465 \\
\hline
\end{tabular}


maximum is 3.815 and the minimum is 0 , the average is 1.414 , and the standard deviation is 0.669 , which indicates that the innovation performance of different enterprises is quite different.

2) Regression analysis

Table 3 is the regression result of the Mode 1-3. Model 1 is the regression result of the influence of the returnee managers on the innovation performance of the enterprise. It can be seen that the regression coefficient is 0.225 , and it is significant at the $5 \%$ significance level, indicating that the higher the proportion of returnee managers, the better the innovation performance, further indicating that the hypothesis 1 is established. Model 2 is the regression result of the returnee managers and the enterprise risk-taking. The regression coefficient is 1.822 , and it is significant at the $5 \%$ significance level, indicating that the returnee managers are positively affecting the risk-taking level of the enterprise. Hypothesis 2 is established. Model 3 is the regression result of returnee managers, risk-taking and enterprise innovation performance. The regression coefficient of returnee managers and corporate innovation performance is 0.215 , and it is significant at $5 \%$ significance level, the regression coefficient of risk-taking

Table 3. Regression result.

\begin{tabular}{|c|c|c|c|}
\hline \multirow{2}{*}{ Variable } & Model 1 & Model 2 & Model 3 \\
\hline & Patent & Z-score & Patent \\
\hline FSM & $\begin{array}{c}0.225^{\star *} \\
(2.05)\end{array}$ & $\begin{array}{c}1.822^{* *} \\
(1.97)\end{array}$ & $\begin{array}{c}0.215^{\star *} \\
(1.97)\end{array}$ \\
\hline Z-score & - & - & $\begin{array}{c}0.005^{\star *} \\
(2.19)\end{array}$ \\
\hline Size & $\begin{array}{c}0.633^{\star * \star} \\
(24.29)\end{array}$ & $\begin{array}{c}-1.126^{\star * *} \\
(-5.12)\end{array}$ & $\begin{array}{c}0.639^{* * *} \\
(24.41)\end{array}$ \\
\hline Growth & $\begin{array}{l}-0.030 \\
(0.622)\end{array}$ & $\begin{array}{l}0.971^{\star} \\
(1.88)\end{array}$ & $\begin{array}{l}-0.035 \\
(-0.58)\end{array}$ \\
\hline LEV & $\begin{array}{c}-0.257^{\star * *} \\
(-3.81)\end{array}$ & $\begin{array}{c}-17.149^{* * *} \\
(-30.14)\end{array}$ & $\begin{array}{c}-0.167^{\star *} \\
(-2.11)\end{array}$ \\
\hline CR1 & $\begin{array}{l}-0.071 \\
(-0.90)\end{array}$ & $\begin{array}{l}-0.241 \\
(-0.36)\end{array}$ & $\begin{array}{l}-0.070 \\
(-0.88)\end{array}$ \\
\hline Pay & $\begin{array}{c}0.195^{\star * *} \\
(4.80)\end{array}$ & $\begin{array}{l}0.713^{* *} \\
(2.08)\end{array}$ & $\begin{array}{c}0.192^{\star * *} \\
(4.71)\end{array}$ \\
\hline Ind & $\begin{array}{l}0.415^{\star} \\
(1.95)\end{array}$ & $\begin{array}{l}-0.739 \\
(-0.41)\end{array}$ & $\begin{array}{c}0.419^{* *} \\
(1.97)\end{array}$ \\
\hline Year & control & control & control \\
\hline Industry & control & control & control \\
\hline Constant & $\begin{array}{c}-0.292^{\star * *} \\
(-4.52)\end{array}$ & $\begin{array}{c}1.440^{* * *} \\
(2.65)\end{array}$ & $\begin{array}{c}-0.299^{* * *} \\
(-4.64)\end{array}$ \\
\hline R-squared & 0.379 & 0.390 & 0.380 \\
\hline Observations & 2464 & 2464 & 2464 \\
\hline
\end{tabular}

Note: ${ }^{* * *},{ }^{* *}$ and ${ }^{*}$ indicate the level of significance of $1 \%, 5 \%$, and $10 \%$, respectively. 
and enterprise innovation performance is 0.005 and it is significant at the $5 \%$ significance level. It shows that for enterprises, the higher the proportion of returnee managers, the stronger the risk-taking ability, the better the innovation performance. According to the median effect test procedure of Wen Zhonglin et al. (2005), when the regression coefficients of Model 2 and Model 3 are both significant, it means that at least part of the influence of the independent variable on the dependent variable is achieved through the intermediate variable. It shows that risk-taking plays a part in mediating between returnee managers and corporate innovation performance, and hypothesis 3 is established.

3) Robustness test

In order to prove the robustness of the research conclusions, this paper replaces the measurement of innovation performance with the number of invention patent applications, and brings it into the regression model. The regression results are shown in Table 4. It can be seen that the returnee managers can still promote the innovation performance of the company by influencing the risk-taking, indicating that the research conclusions of this paper are relatively stable.

Table 4. Robustness test result.

\begin{tabular}{|c|c|c|c|}
\hline \multirow{2}{*}{ Variable } & Model 1 & Model 2 & Model 3 \\
\hline & Invention patent & Z-score & Invention patent \\
\hline FSM & $\begin{array}{c}0.235^{* *} \\
(2.16)\end{array}$ & $\begin{array}{c}1.822^{* *} \\
(1.97)\end{array}$ & $\begin{array}{l}0.223^{* *} \\
(2.05)\end{array}$ \\
\hline Z-score & - & - & $\begin{array}{c}0.007^{\star * *} \\
(2.75)\end{array}$ \\
\hline Size & $\begin{array}{c}0.611^{* * *} \\
(23.61)\end{array}$ & $\begin{array}{c}-1.126^{\star * *} \\
(-5.12)\end{array}$ & $\begin{array}{c}0.618^{* * *} \\
(23.80)\end{array}$ \\
\hline Growth & $\begin{array}{l}0.0284 \\
(0.47)\end{array}$ & $\begin{array}{l}0.971^{\star} \\
(1.88)\end{array}$ & $\begin{array}{l}0.022 \\
(0.36)\end{array}$ \\
\hline LEV & $\begin{array}{c}-0.269^{* * *} \\
(-4.02)\end{array}$ & $\begin{array}{c}-17.149^{* * *} \\
(-30.14)\end{array}$ & $\begin{array}{c}-0.157^{\star \star} \\
(-2.00)\end{array}$ \\
\hline CR1 & $\begin{array}{l}-0.071 \\
(-0.90)\end{array}$ & $\begin{array}{l}-0.241 \\
(-0.36)\end{array}$ & $\begin{array}{c}-0.196^{\star *} \\
(-2.50)\end{array}$ \\
\hline Pay & $\begin{array}{c}0.226^{* * *} \\
(5.59)\end{array}$ & $\begin{array}{c}0.713^{* *} \\
(2.08)\end{array}$ & $\begin{array}{c}0.221^{\star * *} \\
(5.47)\end{array}$ \\
\hline Ind & $\begin{array}{c}0.415^{\star} \\
(1.95)\end{array}$ & $\begin{array}{l}-0.739 \\
(-0.41)\end{array}$ & $\begin{array}{c}0.446^{* *} \\
(2.11)\end{array}$ \\
\hline Year & control & control & control \\
\hline Industry & control & control & control \\
\hline Constant & $\begin{array}{c}-0.253^{* * *} \\
(-3.95)\end{array}$ & $\begin{array}{c}1.440^{* * *} \\
(2.65)\end{array}$ & $\begin{array}{c}-0.262^{\star * *} \\
(-4.10)\end{array}$ \\
\hline R-squared & 0.386 & 0.390 & 0.388 \\
\hline Observations & 2464 & 2464 & 2464 \\
\hline
\end{tabular}




\section{Research Conclusions and Policy Recommendations}

1) Research conclusions

This paper takes 224 listed companies in China from 2007 to 2017 as the research object, and empirically analyzes the impact of returnee managers and risk-taking on the innovation performance of enterprises. Through research, it is found that the proportion of enterprise returnee managers is positively correlated with innovation performance. The higher the proportion of returnee managers, the better the innovation performance of enterprises; the returnee managers can improve the financial stability of enterprises and enhance the risk-taking level of enterprises; the risk-taking is the mediator of the returnee managers and the innovation performance of the enterprises, and the impact of returnee managers on the innovation performance of enterprises is partly realized through risk-taking.

2) Policy recommendations

Based on this, this paper proposes the following policy recommendations: First, enterprises should vigorously implement talent introduction work, actively select and train returnee managers, and use the international vision and unique management experience of returnee managers to enhance their core competitiveness, and giving full play to the positive role of returnees. Second, enterprises should focus on improving their risk-taking ability, constructing a sound risk management system, strengthening internal risk management and enhancing the level of risk-taking of enterprises, thus promoting the innovation and development of enterprises.

3) Inadequacies and prospects

The original data studied in this paper is based on CSMAR's "Characteristics of Listed Companies" database and is manually checked and supplemented according to Sina.com, Hexun.com, Sohu.com, etc, so there may be some errors. In addition, this paper does not refine the overseas background of managers in the process of research, therefore, in the future research, the overseas background of managers can be further divided into overseas learning background and overseas work background, and further explore its impact on innovation performance.

\section{Conflicts of Interest}

The author declares no conflicts of interest regarding the publication of this paper.

\section{References}

[1] Hambrick, D.C. and Mason, P.A. (1984) Upper Echelons: The Organization as a Reflection of Its Top Managers. Academy of Management Review, 9, 193-206. https://doi.org/10.5465/amr.1984.4277628

[2] Cheng, L.T.W., Chan, R.Y.K. and Leung, T.Y. (2010) Management Demography and Corporate Performance: Evidence from China. International Business Review, 19, 261-275. https://doi.org/10.1016/j.ibusrev.2009.12.007 
[3] Zhu, G.J., Wu, Q.B., Dong, S.X. and Zhang, H.Y. (2013) Research on the Relationship between Demographic Characteristics, Incentives and Innovation Performance of Senior Management Team-An Empirical Study from Chinese GEM Listed Companies. China Science and Technology Forum, 6, 143-150.

[4] Han, Q.W., Yang, C. and Gu, Z.P. (2017) The Threshold Effect of Executive Team Heterogeneity on Enterprise Innovation Efficiency-An Empirical Study Based on Listed Companies in Strategic Emerging Industries. China Economic Issues, 2, 42-53.

[5] Liu, X.H., Lu, J.Y., Filatotchev, I., Buck, T. and Wright, M. (2010) Returnee Entrepreneurs, Knowledge Spillovers and Innovation in High-Tech Firms in Emerging Economies. Journal of International Business Studies, 41, 1183-1197.

https://doi.org/10.1057/jibs.2009.50

[6] Wang, X.L., Ma, L. and Wang, Y.L. (2013) The Impact of Executive Team's Functional Background on Corporate Performance: A Case Study of Listed Companies in China's Information Technology Industry. Nankai Management Review, 16, 80-93.

[7] Liu, F.C., Mo, J.X. and Ma, R.K. (2017) Research on the Influence of Overseas Teams' Executive Background on Enterprise Innovation Performance. Management Review, 29, 135-147.

[8] Wang, Y.H. and Zhou, W. (2013) An Empirical Study on the Relationship between the Educational Background of the Top Decision-Makers of the Company and the Risk Acceptance of the Company. Education and Economy, 6, 30-35.

[9] Lu, W.D., Liu, W. and He, W.F. (2015) Manager Heterogeneity and Enterprise Risk Taking. China Soft Science, 12, 120-133.

[10] $\mathrm{Su}, \mathrm{K}$. (2016) Research on the Influence of CEO Background Characteristics on Corporate Risk Bearing. Contemporary Economic Management, 38, 18-25.

[11] Bargeron, L.L., Lehn, K.M. and Zutter, C.J. (2010) Sarbanes-Oxley and Corporate Risk-Taking. Journal of Accounting \& Economics, 49, 34-52. https://doi.org/10.1016/j.jacceco.2009.05.001

[12] Brown, L. and Osborne, S.P. (2013) Risk and Innovation. Public Management Reviews, 15, 186-208. https://doi.org/10.1080/14719037.2012.707681

[13] Liu, H. and Yang, H.M. (2018) Risk Taking and Innovation Performance-Based on the Investigation of the Adjustment Effect of Equity Incentives. Modern Finance and Economics (Journal of Tianjin University of Finance and Economics), 38, 98-113.

[14] Yang, J.J. (2009) Trust, Risk-Taking and Enterprise Innovation Performance. China Management Modernization Research Association. The 4th 2009 China Management Annual Conference-Technology and Innovation Management Sub-Conference. China Management Modernization Research Association: China Management Modernization Research Association, 9.

[15] Wang, L.F. and Hu, Y. (2017) Does Venture Capital Promote Innovation Performance?-An Empirical Test Based on Panel Data of Chinese Enterprises. Financial Research, 1, 177-190.

[16] Jiang, F.X., Zhang, M., Lu, Z.F. and Chen, C.D. (2009) Overconfidence of Managers, Enterprise Expansion and Financial Distress. Economic Research, 44, 131-143. 